eCommons@AKU

January 2007

\title{
Teacher assessment as policy instrument: Contradictions and capacities
}

Constant Leung

Kings College, United Kingdom

Pauline Rea-Dickins

Aga Khan University, pauline.rea-dickins@aku.edu

Follow this and additional works at: http://ecommons.aku.edu/eastafrica_ied

Part of the Educational Assessment, Evaluation, and Research Commons

\section{Recommended Citation}

Leung, C., Rea-Dickins, P. (2007). Teacher assessment as policy instrument: Contradictions and capacities. Language Assessment Quarterly, 4(1), 6-36.

Available at: http://ecommons.aku.edu/eastafrica_ied/43 


\section{Teacher Assessment as Policy Instrument: Contradictions and Capacities}

\section{Constant Leung \& Pauline Rea-Dickins}

To cite this article: Constant Leung \& Pauline Rea-Dickins (2007) Teacher Assessment as Policy Instrument: Contradictions and Capacities, Language Assessment Quarterly, 4:1, 6-36, DOI: 10.1080/15434300701348318

To link to this article: http://dx.doi.org/10.1080/15434300701348318

曲 Published online: 05 Dec 2007.

Submit your article to this journal $\pi$

Џlll Article views: 585

Q View related articles $₫$

4 Citing articles: 5 View citing articles $\asymp$ 


\title{
ARTICLES
}

\section{Teacher Assessment as Policy Instrument: Contradictions and Capacities}

\author{
Constant Leung \\ Kings College, London \\ Pauline Rea-Dickins \\ University of Bristol
}

\begin{abstract}
Assessment has been at centre stage of educational reform in England and Wales in the past 15 years. This article argues that official educational assessment policy is essentially indifferent to the technical, pedagogic, and epistemological issues related to different forms of assessment. Policymakers are primarily concerned with "delivering" educational success in terms of reportable rising levels of attainment. The first part of this article provides a contextualized account of the use of assessment as an educational policy instrument and some of the consequences for pedagogy and curriculum provision. Our focal point here is on the assessment of English within the National Curriculum. The second section of the article amplifies our central argument - that policy is uninterested in the technical and educational issues involved in assessment - by offering a detailed critique of the limited and impoverished nature of the infrastructure and support available for teachers to carry out teacher assessment, with particular reference to the assessment of English for pupils whose first/home language is a language other than English. Research data are used to support our observations and arguments. We suggest that there is an urgent need to clarify the distinctions between summative and formative assessment, between the assessment of English as a first language and English as an Additional
\end{abstract}

Correspondence should be addressed to Constant Leung, Department of Education and Professional Studies, King's College, London, Frankin-Wilkins Building, Waterloo Road, London, SE1, 9NN, United Kingdom. E-mail: constant.leung @kcl.ac.uk 
Language, and between a grammar-based view of English and a cross-curriculum discourse and communication-oriented view of English.

Assessment has played a large part in school education reforms in Britain in the past 15 years. After a decade of heavy investment in standardized national testing of school students, there now appears to be a policy shift in favour of teacher assessment. The aim of this article is twofold: to provide a brief account of the shifting roles assigned by policymakers to standardized testing and teacher assessment as policy instruments to "lever up" school, teacher, and student performance, and to examine some of the unresolved conceptual and practicerelated issues that are at the heart of teacher assessment in the light of the emerging policy initiatives. We discuss the latter issues with reference to English as an Additional Language (EAL). ${ }^{1}$ Appendix A provides a gloss on some of the institutional labels and names mentioned in this discussion.

\section{Assessment and Educational Policy Interface}

The measurement of student academic performance has always played an important role in the maintenance and control of public education. The Scholastic Aptitude Tests (now the SAT Reasoning Test and SAT Subject Tests) in the United States and Advanced Level examinations in Britain are good examples of high-stakes assessment systems primarily designed to measure individual attainment. At the same time, they play an important part in the sustaining of the educational status quo in these countries. It can be argued that the social and political function performed by assessment in education has been given a much higher profile in countries such as Australia, Britain, and the United States since the beginning of the 1990s. There is now a high level of consensus among commentators (e.g., Brindley, 1998; Daugherty Assessment Review Group, 2004; Wiliam, 2001a, 2001b) that the prime reason for this development has been economic, or more accurately the return to ideological prominence of market forces in both international trade and domestic economic policies. For instance, Broadfoot and Pollard (2000) succinctly summarized this powerful and still-growing trend thus:

The 1970s and 1980s had seen a growth in international economic competition. This, together with growing financial pressures and an increased demand for state institutions to be accountable, underpinned a desire to curb the professional autonomy of teachers and to replace it with a much greater measure of central control.

\footnotetext{
${ }^{1}$ In England official school curriculum documents tend to use English as an Additional Language. In practice there is no difference between English as an Additional Language and English as a Second Language, a more familiar term in the international literature.
} 
The underlying rationale here was provided by "New Right" beliefs about the beneficial role of market forces and competition in driving up standards, and controlling "producer interests." . . In such a model, assessment and measurement has a particular role in providing "objective" information on which educational "consumers" such as parents and governments can base their decisions. (p. 13)

Many educational and social programmes explicitly use assessment and the public reporting of assessment outcomes as part of the mechanism of "policy delivery." This increasingly prominent role assigned by policymakers has drawn attention to the complex and sometimes problematic interface between assessment as a specialist professional practice and assessment as policy instrument. For instance, Brindley (2001b, p. 395) reported a public exchange between the director of the Australian Council for Educational Research (ACER) and the officials in the Federal Education Ministry in which the director of ACER was reported to have suggested that "most, if not all states and territories, were dumbing down literacy tests to bring them in line with [the] minimal (national benchmarks) standards."

In another example, the Arizona Department of Education (2004) published a set of school student performance data purporting to show that the structured English immersion $^{2}$ programmes were producing higher levels of achievement in English language, reading, and mathematics than the bilingual programs within the state.

Students in structured English immersion programs outperformed students in bilingual programs in that they were anywhere from one to four months ahead between second and fourth grade, as much as six months ahead in fifth grade, and over a year ahead from sixth grade on. This means that for students in sixth grade and above, students in structured English immersion programs were over a year ahead of students in bilingual programs (Rezzonico, 2004).

These data were used by the officials of the Education Department to justify their preference for the structured English immersion programmes, which were held to be capable of producing better results. ${ }^{3}$ These examples demonstrate how policy imperatives can drive educational institutions to manipulate assessment data to show the policies that they have been promoting in a favourable light.

The focus of discussion in this article, however, is on a different aspect of the assessment and policy interface: the status assigned to standardized tests and teacher assessment as enforcers of policy delivery. Our discussion is informed by

\footnotetext{
${ }^{2}$ Structured English immersion is "a form of English-only education that allows for the smallest amount of native-language instruction necessary to supplement an English-only curriculum" (Arizona Department of Education, 2004, p. 1).

${ }^{3}$ Incidentally, this use of student assessment data to support the state's educational policy was contested by Teachers of English to Speakers of Other Languages (TESOL; 2004) on the grounds of methodological shortcomings and misuse of research data.
} 
some of our research in the assessment of EAL in England in the past 15 years, a period marked by radical across-the-board school curriculum and assessment changes, of which the National Literacy Strategy (Department for Education and Employment [DfEE], 1998) is a current example. We use this as a case par excellence to illustrate the shifting nature of the assessment and policy interface.

\section{TESTING ENGLISH AND ENGLISH LITERACY ATTAINMENTS}

There has been long-standing government concern over the perceived low levels of English and English literacy attainment among 16-year-old school leavers in Britain. Remarks such as "among 16 and 17 year old conscripts to the army in the first year of the second world war . . virtually a quarter were illiterate" and "standards in literacy are much the same as they were 30 years ago" (Barber, 1997, p. 3) are often found in public policy documents. Aligned to this concern for low literacy attainment was the view that the future well-being and competitiveness of the country depended on the availability of a highly educated and skilled workforce to take advantage of the "knowledge-based" economy. A high level of literacy (and numeracy) skills was seen as a key ingredient in the making of competitive and productive workers in the 21st century. When the New Labour Party came into office in 1997, only 63\% of the 11-year-old pupils achieved Level 4 or above in the National Curriculum English tests. A policy priority was therefore put in place to drive up standards in literacy attainment among the school pupils. A number of attainment targets were set for key subject areas in the school curriculum. This discussion focuses on the key English and English literacy attainment targets for 11-year-olds in England and Wales ${ }^{4}$, which are as follows: "By the end of a second term ${ }^{5}$ of a Labour government, all children in primary school will achieve at least Level 4 in reading in the National Curriculum by the age of eleven" (Barber, 1997, p. 7). "By 2002: 80\% of 11 year-olds will be reaching the standards expected for their age in English [Level 4 or above]" (DfEE, 1997, p. 19).

The levels of attainment mentioned in the target statements are set out in the National Curriculum English attainment scales. The National Curriculum subject English has eight levels of attainment covering the ages of 5 to 14 (see DfEE \& Qualifications and Curriculum Authority (QCA), 1999; Appendix B for English Level 4 descriptions). Pupil attainments are assessed by standardized tests and teacher assessment. However, only the standardized test scores have been used

\footnotetext{
${ }^{4}$ There is local variation in the political administration within the constituent parts of the United Kingdom. For this reason our comments in this article are largely related to England.

${ }^{5}$ The end of the second term of the New Labour government was June 2005.
} 
for public reporting. There has thus been official privileging of standardized tests for measurement and accountability purposes, despite a general policy that standardized tests and teacher assessment have equal status (e.g., QCA, 2004a,b). There are at least two reasons for this. First, in England politicians have been skeptical about schools' ability to carry out assessment effectively (e.g., Henry, 2001). ${ }^{6}$ This is a very important consideration in an educational environment, where so much has been invested in improving school attainment (itself measured and defined by various test scores). For the government, the basis of any claimed gains has to be seen to be credible. Second, (some) teachers have been tacitly held responsible for the "low" levels of attainment in English and English literacy in the discourse of the critics of liberal teaching practices (e.g., Honey, 1997). The Education Secretary is reported to have said, "National tests are key to ensuring that children in poorer areas do not get left behind. They provide objective national standards and help raise expectations locally" (as cited in Spencer, 2004, p. 3). In fact, standardized tests were seen by the government as a mechanism to "lever up" attainment (Association of Teachers and Lecturers, 2005). In one way or another, teachers were not deemed to be trustworthy in the key task of assessing attainment. Indeed, primary teachers were, on the whole, seen as in need of upgrading and assistance. The curriculum specifications and the associated teaching guidance for the National Literacy Strategy (DfEE, 1998) (and all subsequent revisions), for instance, have been designed for this purpose.

\section{THE NATIONAL LITERACY STRATEGY}

Given the public commitment to raising English and English literacy attainments, an energetic, high-profile, and well-resourced teaching programme, the National Literacy Strategy (DfEE, 1998), was introduced in primary schools. This Strategy, inter alia, recommended a highly prescriptive literacy teaching programme (see Appendix C), a daily Literacy Hour lesson devoted to the teaching of literacy, and a highly structured teaching methodology with a four-part division of the Literacy Hour (see Appendix D). In addition, teams of "literacy consultants" were sent to schools to assist teachers in the implementation of the Literacy teaching programme. For a time it would seem that no trouble was spared to ensure that the set targets were achieved.

The test results of the past 10 years, however, show rather chequered progress. In terms of reading, 84\% of the 11-year-olds achieved Level 4 (or above) in 2005 (National Statistics, 2005), the end of the second term of the New Labour

\footnotetext{
${ }^{6} \mathrm{~A}$ former chief executive of the Qualifications and Curriculum Authority publicly stated, "The present testing regime was set up because politicians did not trust schools” (as cited in Henry, 2001, p. 2).
} 
government. So, the "all children in primary school will achieve at least Level 4 reading" target has not been achieved. In terms of the overall subject English, the test results since 1996 are as follows.

Quite clearly the target of $80 \%$ set for 2002 was not achieved. Indeed, it has not been achieved even in 2005 (albeit by a small margin). The figures in Table 1 suggest that rapid gains were made between 1996 and 2000. Given that the National Literacy Strategy was only introduced in 1998, it would seem that the momentum for the 18\% increase between 1996 and 2000 had started before the onset of the efforts of the National Literacy Strategy. The levels of attainment, as measured by standardized tests, were rising anyway. After 2000 the attainment level in England was static for 4 years at $75 \%$. The next increase, to $78 \%$, was reported in 2004. Seen in this light, the setting of attainment targets, which have been systematically supported and reinforced by statutory tests and a highly regulated and prescribed teaching regime, may have just begun to register its effect, if at all, after 6 years of implementation. It is, of course, very difficult to say with any certainty what contributed to the increases and the stasis in this period by just looking at the annual percentages. One thing is clear, though. Between 1997 and 2004 the government had been under constant pressure to account for the apparent failure to meet its own self-imposed targets in English and English literacy attainment. We comment on the consequences of this policy "failure" in a moment. Before that, we provide a brief discussion on the annual attainment figures between 1996 and 2005.

TABLE 1

Percentage of Pupils Achieving Level 4 or Above English Between 1996 and 2005

\begin{tabular}{lc}
\hline Year & \% Pupils Achieving Level 4 or Above in English \\
\hline 1996 & 57 \\
1997 & 63 \\
1998 & 64 \\
1999 & 70 \\
2000 & 75 \\
2001 & 75 \\
2002 & 75 \\
2003 & 75 \\
2004 & 78 \\
2005 & 79 \\
\hline
\end{tabular}

Note. The annual National Curriculum test results can be found on United Kingdom government agency Web sites such as http://www.dfes. gov.uk/rsgateway/DB/SFR/s000595/index.shtml, http://www.archive.officialdocuments.co.uk/document/ofsted/ped/ped.htm, and http://www.statistics.gov. uk/CCI/nscl.asp?ID=6137 
At first sight the large increases in attainment between 1996 and 2000 appear to be dramatic. Timms and Fitz-Gibbon (2001) studied comparable data on reading attainment covering this period and found that the National Curriculum test results in this period were unique in reporting this "impressive rise"; other studies in England surveying reading standards in the 1980s and 1990s show minor year-to-year fluctuations, but none reports a continuous gain. Given the lack of corroborating evidence of large increases in attainment in English pupils during this period, the reported increases must be treated with a degree of caution. Timms and Fitz-Gibbon suggested that the increases might have been accounted for by a lowering of test "standards" associated with a number of operational problems such as lowering of cutoff scores making it easier to achieve higher grades, and inadequate anchoring of test scores leading to a drift in standards over time. On this last point, Timms (2004) suggested that the rather unusual disjuncture between the pre- and post-2000 patterns of attainment was largely accounted for by "the shift from equating standards only to the previous year to maintaining standards over several years" (p. 492), which took place in 20002001. Given the complex bureaucratic nature of many aspects of test development and test administration involving many different government departments and agencies, it would seem that we are unlikely to ever get to a historically accurate understanding of the reasons for the "impressive rise" in these years. ${ }^{7}$ The important point here for us is that much of the reported gains have still to be explained, and this in itself has an undermining effect on any claim of policy success (also see Association of Teachers and Lecturers, 2005).

At the same time, there is a good deal of evidence that the target-oriented and test-driven approach has led to the twin effect of "teaching to the test" and narrowing of the curriculum. For instance, in a government-commissioned evaluation of the National Literacy Strategy, Earl et al. (2003) stated that

From the data available to us, we see some evidence that the high political profile of the 2002 national targets skewed efforts in the direction of activities that would lead to increases in the one highly publicised score. Many teachers acknowledged that they "teach to the test" (p. 137).

This finding is often given real-life expressions in angst-ridden teacher stories reported by the educational press. For instance one Year 6 teacher was reported to give this account of her work:

In the spring term, I drop design and technology, music and religious studies. . . . Because of the tests, I sometimes focus on children who might reach level 4 with a

\footnotetext{
${ }^{7} \mathrm{An}$ example of the interagency complexities involved in unravelling the issues can be seen on http://www.statscom.org.uk/media_pdfs/meetings/meeting14/SC2002-70.pdf
} 
little boost. My ideal would be that all children get the same amount of time. But coming up to the tests I spend three days a week with the booster children. I sit with them because they're the ones who increase the results. How awful is that? (Ward, 2004, p. 18).

There are also whistle-blower accounts by classroom teachers who clearly feel that the tests have distorted professional values. For instance, one teacher wrote anonymously, "I know of a senior member of staff who has regularly delayed submission of completed papers to allow pupils to correct their answers well after the original test day" (Anonymous, 2004, p. 8).

\section{THE RETURN OF TEACHER ASSESSMENT}

The persistent failure of the test results to meet the official targets has undoubtedly caused consternation among policymakers over the past few years. At the same time, the cumulating evidence of the deleterious effects of the focus on test scores has pointed to the futility of the target-setting exercise, if the targets were meant to "lever up" attainment in the first place. Meanwhile the educational case for "assessment for learning," that is, formative assessment carried out by teachers, was gradually gaining credibility and momentum. The widely disseminated work of the Assessment Reform Group (2002); Black, Harrison, Lee, Marshall, and Wiliam (2002); Black and Wiliam (1998a, 1998b); and others demonstrating that systematic formative assessment could raise standards of achievement was making it difficult for policymakers to persist in their course of action.

In these circumstances it was therefore not surprising that by 2001 there were early signs of change in the air. The government's chief examination adviser was reported to have said, in a speech at a conference organised by the government curriculum authority, that "most teachers were incapable of making reliable judgements about pupils' performance a decade ago" and that the curriculum and testing reforms in the 1990s had "transformed teachers' understanding of what is to be taught and learned and their competence to assess what pupils achieve," and for that reason teachers should be given a bigger role in assessment (Henry, 2001, p. 2). The case for teachers having a more prominent role in assessment was being rehearsed in curriculum documents. For instance, the 10 principles for classroom-based formative assessment published by the Assessment Reform Group (2001) have been referred to, in various forms, on the Web site of the official curriculum authority, QCA, since 2001.

In May 2004 the Welsh Assembly Government, now enjoying a degree of political autonomy in the devolved British political system, announced that the school system in Wales would abandon national standardised tests for 11- and 14-year-olds by 2007 . This political decision came after the publication of the 
Daugherty Report (Daugherty Assessment Review Group, 2004) which, inter alia, states that

It is clear that test preparation and practice, a narrowing of curriculum coverage and styles of learning that contribute to good test performance have become prominent features of the Year 6 experience of pupils in many schools. ... The Group has considered whether end-of-key-stage testing, in terms of the "hard" data it gives us on pupil attainments and the targets it gives some pupils to aspire to, is of sufficient value to compensate for the evident impoverishment of pupils' learning that is occurring at a critical stage in their educational development. (section 3.4)

From 2007 on, teacher assessment will be used for statutory attainment reporting at the ages of 11 and 14 in Wales. In the meantime, in England the government published a new primary education policy document entitled Excellence and Enjoyment (Department for Education and Skills (DfES), 2004), which sets out to signal a willingness to give teachers and schools greater say in teaching and learning matters. The publication of this policy document prompted an educational press editor to remark that

While it was agreed that the national literacy and numeracy strategies . . . had raised standards and boosted teachers' skills, national test results had levelled out. . . The primary strategy document, Excellence and Enjoyment, is meant to give teachers permission to break free of prescription, and to use their own judgement about the needs and learning styles of their pupils. It stresses that fun and innovation can and should go hand in hand with high standards in English and maths. (Hofkins, 2004, p. 2)

In 2004 the official curriculum authority in England announced that beginning in September 2004 teachers working with children between the ages of five and seven would carry on administering the National Curriculum tasks and tests in reading, writing, and mathematics, and they would continue to use the outcomes to inform their own overall assessment of a pupil's progress. The new approach from September that year was to use national tests and tasks to underpin teacher assessment, but the teacher assessment level (not test results) would be reported nationally (QCA, 2004a).

It would seem that the current policy shift is in favour of teacher assessment, after some years out in the cold, so to speak. Teacher assessment is now articulated to the policy requirements of making teaching and learning fun and innovative and raising "standards." At this juncture two questions seem pertinent: How is teacher assessment conceptualised in the official assessment framework, and what, if any, are the implementation issues at the classroom level as revealed by research? We examine these questions with reference to the assessment of EAL children in mainstream schooling. 


\section{CONTEXT OF EAL ASSESSMENT}

The analysis that we present next comes from the educational context in England where language minority children with EAL are learning alongside English first-language (L1) speakers in mainstream primary (elementary) classes in England. ${ }^{8}$ The teachers involved may be mainstream teachers and/ or language support teachers both of whom, in turn, may be supported by (sometimes bilingual) teaching assistants. Those learners working through EAL are expected to acquire subject knowledge and English language skills simultaneously. Some of these learners will have reached a level of English language proficiency considered adequate for them to access the curriculum independently (i.e., as English L1 speakers). Others, however-these are in the majority in the research context reported here-are considered to be "at risk" on account of weak English language skills and, for this reason, require additional language support provided by their teachers, whether mainstream or language support.

Thus, within this specific instructional context there are challenges that are particular for teachers of EAL learners who need to assess not only subject knowledge but also both the learners' English language progression and attainment. By progression, we refer to the processes through which teachers support their learners by providing diagnostic feedback of various kinds. In the general education assessment literature, a number of feedback frameworks have been developed (e.g., Tunstall \& Gipps, 1996), and in the work of Black, Harrison, Lee, Marshall, and Wiliam (2003) and Torrance and Pryor (1998) particular emphasis is placed on the nature and role of teacher-questioning strategies in formative assessment. There are obvious links, too, with the second language acquisition literature (see Rea-Dickins, in press) and the ways in which teacher feedback on language-for example, through recasts and corrective feedback strategies (e.g., Loewen, 2004; Panova \& Lyster, 2002)—affect the ways in which learners subsequently use the linguistic item that was the focus of the teacher's feedback.

\footnotetext{
${ }^{8}$ The data were collected for the research project: Classroom Assessment of English as an Additional Language: Key Stage 1 Contexts, ESRC Major Research Grant R000238196, 1999-2002. Available at http://www.esrcsocietytoday.ac.uk/ESRCInfoCentre/ViewAward Page.aspx?data=\%2fFrXHT1993oBn\%2f\%2fgKlxUDEIxcnfn8e239BDDlp $\% 2 \mathrm{bm} 1 \mathrm{I} \% 2 \mathrm{bm} 6 \mathrm{emcH}$ yDKWZ7TMEGM2bJU2qzJ50GDTUby6Uo5DVZa\%2bBcAyOdnGuigPWmgeyNVMuFZlkf7Yo BLXdkPuO1M4AOHCO4tNYcT\%2b6Kt81HssQ0y2wCwEq3iwJEOyWU5omc205GxRMreCQ FwK7SnTnLidVw4bi3xCSVRiShvWQbEJccIriFAZZ6VHjOQHU7RpQ\%2fizG4EkeMx\%2bJC HmioV0k86nxbNaeXBnTLaZLbN46sYYv8G31h8oCFd2meycomS90BhRHM\%3d\&xu=\&isAward Holder $=\&$ isProfiled $=\&$ Aw $\operatorname{ardHolderID}=\&$ Sector $=$.
} 
Below, we first critique some of the policy discourse that aims to inform teachers about the assessment of learners with EAL working in the mainstream before analysing the tensions that exist for teachers as they undertake their different roles as "classroom language assessors."

\section{OFFICIAL GUIDANCE FOR TEACHER ASSESSMENT FOR EAL}

In this section we analyse a key curriculum document provided to inform teachers' thinking and guide their practice in the assessment of learners with EAL: The Assessment of Pupils Learning English as an Additional Language (DfES, 2003). This document is divided into six sections (13 pages), the first of which presents "principles of assessment." Citing from another curriculum guidance publication, A Language in Common (QCA, 2000), this document states the following:

Effective assessment for all pupils should:

- recognise what pupils can do and reward achievement

- be based on different kinds of evidence

- be a valid reflection of what has been taught or covered in class

- be reliable in terms of enabling someone else to repeat the assessment and obtain comparable results

- be manageable, both in terms of the time needed to complete the task, and in providing results which can be reported or passed on to other teachers. (DfES, 2003, p. 2)

At first glance this might appear unproblematic, especially as the following statement precedes this list: "The focus is on how data gathered through assessment of learning can be used formatively and feed back into classroom planning, teaching and learning" (DfES, 2003, p. 2) On closer examination, however, nothing is specifically stated or referred to in relation to:

1. Monitoring learners' emerging language awareness and development: It is achievement that is mentioned.

2. Assessment as integrated within instructional discourse: Mention of what has been "taught or covered" is suggestive of an assessment of achievement or a diagnostic assessment in relation to a one off measurement focused assessment.

3. Formative assessment as an on-going process: The notions embedded within "reliability," "repeat the task" resonate not with in-flight classroom assessment-in which the expectation is that teachers' feedback strategies are prominent—but much more with an assessment activity that is stand 
alone, one that can be replicated and that meets the traditional testing criteria of validity, reliability, and practicality. This positions the teacher within a "testing" paradigm (see Teasdale \& Leung, 2000), without due attention to ongoing teacher assessment embedded within instruction. Findings of a number of research studies into classroom assessment practices suggest that classroom assessment data will be messy, and it is only over time through the accumulation of data on individual learners that a teacher builds up a valid and comprehensive picture, that is, data accumulated and interpreted through iterative teacher processing (e.g., Black, 1998; Rea-Dickins \& Gardner, 2000).

Our interpretation in the third point is further supported by the point made in The Assessment of Pupils Learning English as an Additional Language (DfES, 2003 , p. 3) that draws attention to "time needed to complete the task" to "results" and to data that can be "reported or passed on": where in this discourse is there a conceptualization of iterative and sustained teacher-pupil or pupil-pupil feedback within interaction?

Any understandings of the nature of classroom formative assessment that might have been gleaned from the aforementioned are firmly swept away in section 2 of the document, which presents the case for a particular way of recording student progress: "To show progress schools need to record entry levels of pupils for whom English is an additional language and compare them with levels at the end of a significant period" (DfES, 2003, p. 4, cited from QCA, 2000).

This statement is given a graphic realization. From Table 2 we may observe in the two right-hand columns how student progress is expressed in terms of the National Curriculum levels of achievement (i.e., Level 3 or 4) on Key Stage 2 tests in English (as a first language), also broken down according to the skills of Reading, Writing, and Speaking, and in Math and Science. Thus progress may be seen to equate with individual performance on statutory tests. Further guidance is provided for teachers: "Most importantly, a school needs to collate all pupil data and records of progress, and translate this information into curricular targets in order to maximise progress for EAL learners" (DfES, 2003, p. 5).

In summary, progression as just evidenced relates to monitoring levels of performance, undeniably one facet of classroom-based assessment. (It is interesting to note the emphasis on input-output measurement, the standard tool of corporate managerialist educational regimes). However, there is no evidence of progression used in the sense of monitoring a learner's developing language awareness and use of language as part of content learning. The same comment even applies to section 3 that asserts to be about using assessment data "to inform teaching and learning." Consider the following: "Setting targets will not, on its own, raise 


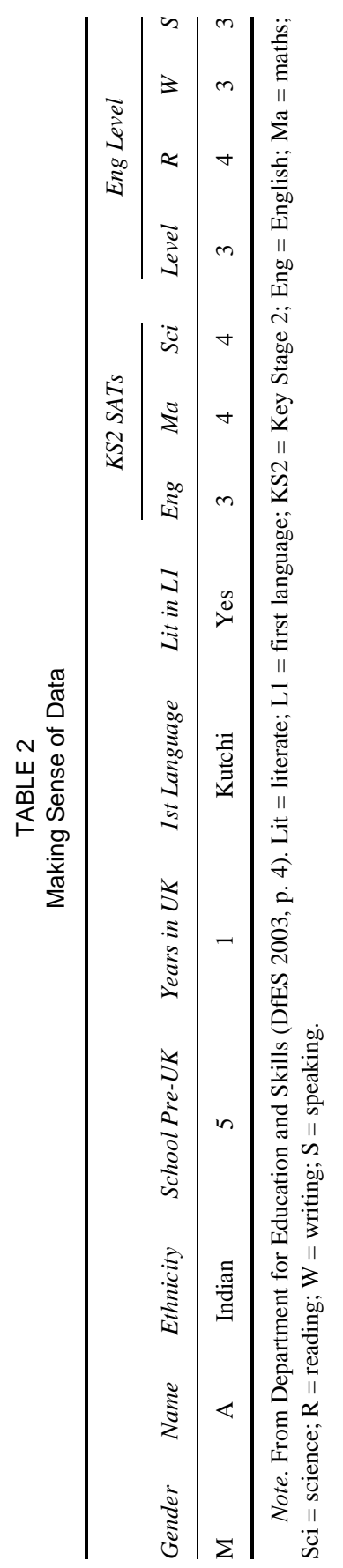


standards of achievement. This will depend on the timely and skilful intervention by teachers" (DfES, 2003, p. 6, citing Ofsted, 2003).

Two case studies are presented (DfES, 2003, pp. 6-7; both of which are reproduced in full as Appendix E), but what permeates each of these is a view of learner assessment that involves

- Target setting and assessment of achievement toward these goals

- A termly review

- Monitoring of support for learners through an intervention sheet

- An analysis of writing samples twice a term linked to three learner-specific targets

Again, there is nothing intrinsically inappropriate about the type of assessment and support suggested. Rather, the absence of any reference to assessment within classroom discourse (e.g., Leung \& Mohan, 2004; Rea-Dickins, 2001) fails to provide teachers with a balanced perspective on the nature of classroom language assessment, focusing as it does exclusively on measuring summatively learner performance.

The examples provided also portray a very static perspective on assessment that foregrounds two points: first, that teachers' formal comments on pupils' work feed back into curriculum planning and teaching, and second, that teachers should audit samples of students' work and identify errors. This, in our view, assumes assessment as a one-way process (which it is not): from teacher to learner, with the teacher in control. It does not link into current perspectives on effective classroom assessment as embedded within interaction and on learner agency in assessment processes, thus failing to take into account the actions that the learners themselves might take in this process (Black et al., 2003; Rea-Dickins, 2006). Further, the advice provided for teachers in the analysis of learners' samples of work fails to take account the discoursal nature of much classroom assessment, as evidenced in the next, again oversimplified, example (see Table 3). We would not dispute the relevance of a description such as the appropriate use of tenses in terms of a learner's developing language competence, as they are crucial to effective language use across the curriculum. But, on the other hand, how valid is this description? The picture just described of the "staged" development of tenses is not only grossly oversimplified but also at odds with what we know from second language acquisition research, which suggests that development is characterized by "backsliding" and other kinds of nonlinear behaviour (Mitchell, 2001). In this particular document, then, the guidance would seem to suggest that (a) the descriptions of language development are based on a somewhat narrow "traditional" view of language (but see the upcoming discussion) and (b) are of dubious and untested validity. However, from our experience working with teachers, we suggest that tense usage, as previously defined in Table 3 , is probably the 


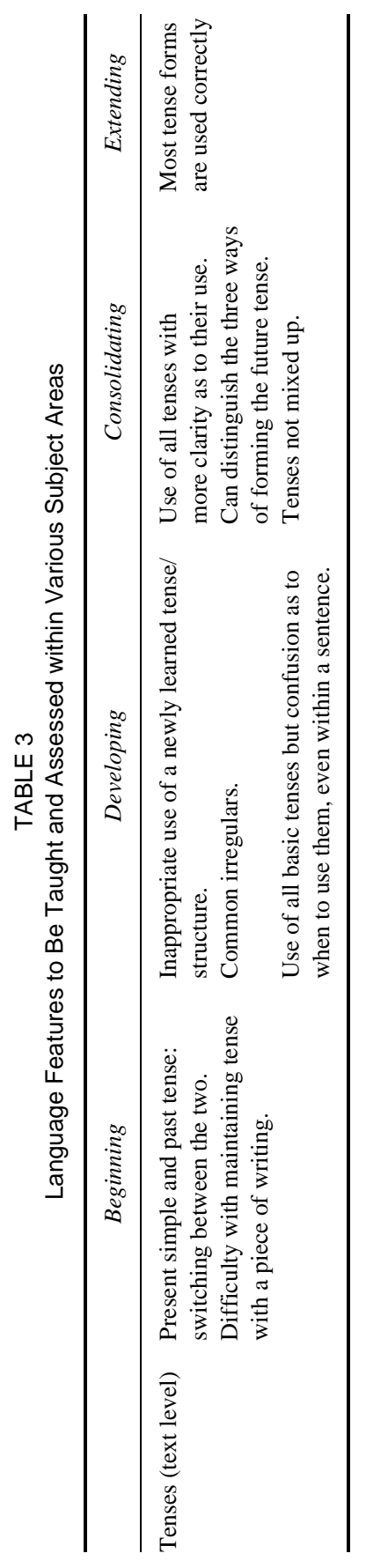


area with which teachers are the most familiar. Areas such as the more complex and subtle uses of modality, as one example, will be less familiar for some teachers (evidenced in Rea-Dickins \& Gardner, 1998) are not touched upon. Neither is it clear what teacher intervention might be on the basis of their "auditing samples and identifying errors"; nor is there mention of cross-curricular specific demands as in, for example, the "reporting of an experiment" or "making predictions" in science. In summary, in this particular guidance document, the examples are not expressed in functional terms but are morphosyntactically focused, thus portraying a view of language that is as narrow as the view of assessment.

Section 4 of the document has the heading "Assessing and Tracking New Arrivals." Again, although the rhetoric asserts the need to monitor student progress and needs, the case study example provided mentions "a short assessment interview"disembedded, we assume, from routine instruction - and the assessment of "writing levels using QCA steps or National Curriculum writing levels" to ensure curriculum support "carefully targeted to meet individuals' needs." Further on (DfES, 2003, p. 9), "half-termly assessment" is mentioned. The point that we wish to make here is that although initial and regular monitoring/tracking of learners is certainly relevant and appropriate, teachers reading this document are being directed more toward assessment performed as extraneous to the learning process and asked to collect and analyze assessment data on the basis of which learners are assigned to a particular level, that is, their language achievement is being measured. Alternatively, mention is made of how teachers should identify areas of learner difficulty to develop curriculum targets, that is, assessment that informs teacher planning. What are not provided at all within the document are examples of how teachers may formatively assess their EAL learners within classroom interaction. There is no mention of capturing, analyzing, and feeding back on spontaneous language use in the classroom (see Rea-Dickins \& Gardner, 2000).

On page 11 of this guidance document, teachers are told that they "should be clear about the purpose of the assessment, distinguishing summative, formative and diagnostic aims." On the final page of the document (p. 13), reference is made to assessment that would function as formative for teachers: "Encourage all departments/teachers to implement regular assessment for learning; assessment practices that immediately inform planning and teaching."

Laudable and appropriate as this statement and goal for the teacher may be, there has been no attempt in this piece of teacher guidance to provide examples on how to achieve this (cf. National Languages and Literacy Institute of Australia, 1994; TESOL, 1997). Black (1998) made a similar point when he compared the amount of teacher time spent on marking tests and "the complete lack of support normally given to teachers in devising and applying procedures to pinpoint students' learning problems, with the virtual absence of outside agencies to develop formative assessment" (p. 104). In summary of our analysis of this official assessment discourse, we observe the following: 
- The conceptualization of assessment is about setting targets, measuring achievement towards those targets: the rhetoric is firmly fixed in the paradigm of summative assessment of achievement.

- Assessment at the discourse level enacted through classroom interactional opportunities is completely absent: Teachers effectively are expected to perform in the role of "rater/examiner."

- A total absence of any reference to learner involvement in the assessment process, one of the key principles of the Assessment Reform Group (2002) framework.

- No explicit mention of language use across the curriculum and the assessment of learners in the different subject activities and discourses.

- No explicit acknowledgement of the distinctive EAL developmental trajectories (beyond the beginning stages of very young bilingual children).

It is inevitable, perhaps, given the value accorded to the measurement of learner performance and the need to document progress in terms of levels (standards), that specific challenges and tensions arise for teachers in fulfilling their different roles in assessing and testing their additional language learners. We illustrate some of these in the next section.

\section{SOME ISSUES IN PROFESSIONAL PRACTICE}

We first consider teacher attitudes toward assessment, which can shape practice in a significant way. It is not surprising that attitudes vary. The prominent discourse on target setting constitutes a powerful one for some and is reinforced through professional publications such as Teachers. In an article responding to media criticisms of testing, Wilce (2003) had this to say:

Some pupils need more support than others in certain areas of learning than others. Equally each child is unique, with his or her strengths and weaknesses which will change and develop as they progress through their education. In view of this, tests and test results have a vital role to fulfil in helping teachers keep abreast of how individual pupils are getting on and informing their professional judgment about how teaching and learning should move forward in their classroom. (p. 14)

She also provided support for her view, as in the following quote from Jennie Newman, a teacher at Silsoe Lower School:

Tests do help you to look at the class as a whole and see who, statistically, is not keeping pace. .. . They can confirm a suspicion you might have that something is wrong, or highlight that a pupil is generally doing well but has real difficulties with, say, spelling. Target-setting for individual pupils is also a very good thing. (p. 14) 
Wilce (2003) also asserted, "When they are administered carefully tests can also help motivate children while intelligent target-setting boosts both motivation and expectations. In addition, test results give parents valuable information about how their child and their child's school is doing" (Elementary school teachers in Spencer, 2003) (p. 14).

These examples would seem to suggest a total "buy in" of "one-stop testing" to meet all needs, although it is not clear whether Wince either was interested in or asked about other purposes and types of assessment. Other professionals, however, do demonstrate awareness of an assessment discourse other than testing and measurement, as evidenced in the following interview extracts in which teachers were asked to talk about the ways in which they approach the assessment of their learners with EAL (Rea-Dickins \& Gardner, 1998):

Assessment using the spontaneous comments ... of the children is very important. (p. 22)

The one that we've been doing in Year 1 was actually a science assessment that was curricular-based. . . . But it led me to see how brilliantly it gave the children the opportunity to use exploratory language and to use reasoning. (p. 22)

I write things down . . . but then a day later . . . he says something and he's always saying that, and I would write it down . . . because then I know he's not progressed. (p. 26)

These comments do not appear to say much about the different assessment roles for teachers in the classroom in which

1. They evaluate (i.e., test and measure) levels of learner performance: for example, as baseline data or regular review throughout a school year, to inform curricular planning and target setting.

2. They evaluate learners and "certify" their achievement as part of statutory reporting at the different Key Stage Assessments, or as part of a local funding project/initiative.

3. They provide structured support for their learners' English language development and achievement.

In the first two respects (Points 1 and 2 here), teachers are functioning in the roles of test developer and rater/examiner: test developer in that they need to select and/or develop an appropriate assessment activity; rater/examiner in that they need to rate reliably and "certify" a learner's performance against a prescribed standard or set of criteria. The problematics of rater training, test moderation processes and issues of developing and sustaining reliable judgments of learners' language performance have long been the focus of many studies in the domain of language-proficiency testing (e.g., Lumley, 2002; McNamara, 1996), 
but such studies relating to classroom language assessment are rare (although see Brindley, 2001a; Clarke \& Gipps, 2000; Leung, 1999; Leung \& Teasdale, 1997). In an earlier project, ${ }^{9} 30$ teachers were asked to identify what they perceived as most important in their assessments of both the language development and achievement of their learners with EAL. As illustrated in the following quotes from Rea-Dickins and Gardner (1998), the teachers themselves are aware of the issues involved when rating learner performance:

Moderation in assessing learners with EAL . . . especially important working towards SATs [National Curriculum tests] in year 2 where teacher assessment is necessary (p. 22).

Moderating grades given both within schools and between different ... staff and across schools (p. 22).

Subjectivity is often a factor in grading (p. 22).

Assessment ... of the children is very important but only of any use if accurate (p. 22).

The need for comparability of context for some assessment. This allows for moderation, for sharing of evidence with mainstream teachers and for gathering information for both oracy grades and NC levels (p. 20).

These comments, we suggest, reveal certain teacher knowledge about the examining/rating process, in particular that

- Subjectivity can be a problem

- Reliability is important when the stakes are high (i.e. SATs)

- Grading within and across schools can be an issue and that moderation is required

This raises the question of the extent to which teachers are trained for the roles of test developer and examiner. Are they? If so, what training is available?

Another facet of the teacher-as-rater/examiner role has to do with the interpretation of the assessment standards. There is evidence to suggest a lack of understanding of some of the descriptors, illustrated in the following quote from Rea-Dickins and Gardner (1998):

I find there are times when they're sort of hinged on an understanding of grammar that I might not necessarily have. So I think there are times when they could be based more upon examples rather than saying, 'Uses modal', whatever they are (p. 23).

\footnotetext{
${ }^{9}$ Research Project funded by Minority Group Support Services, Coventry Education Service, 1997-1998. Immense support in facilitating this project in schools was provided by Sandra Howard and Chris Shearsby, who made this research possible.
} 
The research of Arkoudis and O'Loughlin (2004) in Australia into teachers' interpretation and use of assessment standards also shows how the teachers they were working with expressed dissatisfaction with the descriptors they were expected to use and wanted finer distinctions made, in their case, in respect of vocabulary, tense, and syntax. Their research further revealed the tensions that their teachers experienced in their role as "raters."

This was in part due to the conflicting demands of reliability and validity and in their roles as 'assessors' and 'judges' of student work, mediated through a largely bureaucratically oriented assessment framework versus their role as teachers supporting the language development and monitoring the language progress of [English as a Second Language] students (p. 295).

An interesting perspective on the teacher-as-rater is provided by Davison (2004) in a comparison of the assessment practices in Hong Kong and Australian secondary schools. Davison revealed how different teacher beliefs and attitudes affect the ways in which teachers judge. Specifically, she identified five different teacher-rater orientations: "technician," "interpreter of the law," "principled yet pragmatic," "arbiter of "community values,"” and "assessor as God." These rater characteristics, she suggested, have significant implications for teacher support:

If a system puts all its faith in fixed, published and imposed assessment processes and criteria —and assumes that no other teacher support is needed — then it will inevitably construe the teacher as a technician who is supposed to 'tick the boxes' and produce a seemingly objective response (p. 327).

Essentially, this is what is happening much of the time when learners are assigned to a National Curriculum level of attainment, as per the official guidance just analysed. Following Davison (2004), the implication of this may be as follows:

The lack of attention to the underlying social context-and the very different and even conflicting cultural and belief systems of teachers and their assessment processes-may lead to teachers recontextualising, distorting or transforming published assessment criteria, or relying on their own unexamined, unarticulated assumptions about shared constructs (p. 327).

Further, there is sometimes a close tie between student performance, and teachers' own and their schools' accountability, as Arkoudis and O'Loughlin (2004) observed: "During the first moderation session, the teachers were preoccupied with the accuracy and objectivity of their assessment because of the link between student performance and their own professional accountability" (p. 295).

Turning next to the role of the teacher in assisting the language performance of learners, we suggest a number of inhibitors to quality formative language assessment. 
First, the time pressure and need to cover the syllabus may squeeze out language development opportunities for learners (e.g., Rea-Dickins, 2006). More recently, Scott (2005) found that the potential for formative assessment to inform individual pupil support may be constrained as teachers negotiate the tension between meeting the needs of the many and of the individual in preparing children for National Curriculum tests. In addition, there is a tendency to apply test criteria in formative assessment, increasingly so as the period for the tests approaches (a point also raised in the earlier section "The Return of Teacher Assessment").

Second, Scott's (2005) research also revealed that target setting may limit the focus/content of language development opportunities with language support work both channeled toward and influenced by test content. As one example, she cited an intensive focus on a limited number of aspects of language use in preparation for the English tests.

The imperative to meet targets may also mean that some learners, rather than all, are provided with additional language support to "ensure" that they reach the requisite level. Scott (2005) found that these learners are selected on the basis of who is more likely to achieve in the formal examinations: "LEAs [Local Education Authorities] were directed to focus on individual borderline pupils, to institute booster classes, and to ensure that teachers and pupils were prepared for the changes to the tests for that year (Ward 2003)" (Scott 2005).

The consequence of such action is that the examination results obtained will match with teacher/school targets, but it also raises a serious equity issue. This latest finding bears out the anecdotal reports mentioned earlier in "The Return of Teacher Assessment" section.

Further, the absence in the official discourse of an interactional perspective on formative language may result in a lack of teacher preparedness to engage in language assessment opportunities that are actually formative for the learners (as opposed to the teachers). Leung and Mohan (2004), for example, suggested that the teacher-student, student-student discourse around decision-making interaction can include opportune moments for teacher to carry out formative assessment. Researching in the foreign rather than additional language learning classroom, Edelenbos and Kubanek-German (2004) wrote about the importance of a teacher's "diagnostic competence."

Evoking a student's prior knowledge and integrating it on an ongoing basis is of general and paramount importance (Brandsford et al., 2000). Teachers who have the ability to evoke and skilfully evoke and exploit this can, for example, ask the right questions or give appropriate feedback (p. 279).

In summary of the glimpses of teacher views and teacher practice presented in this section, we assert that the complexities underlying teacher assessment are seriously underarticulated. We have shown that in a teacher-as-rater role, the 
rating process in which teachers engage is made up of layers of complexity: some related to good practice-as in the need for rater reliability, others related to systemic tensions within the assessment context-from bureaucratic pressures on the school and teachers for accountability and achievement of targets. In their role as supporting language development, there is far too much left unsaid. A serious consequence of this positioning is that teachers will adopt a view of assessment as summative, a conclusion drawn by the classroom-based empirical studies of Rea-Dickins (2002) and Black et al. (2003).

\section{TEACHER ASSESSMENT: NEW STATUS, UNDERREHEARSED PREPARATION?}

Given its heavy focus on target setting and summative judgments on a learners' performance, it is arguable whether the current available "official" discourse on assessment is of much practical use to inform the implementation of high-quality teacher assessment. In terms of summative assessment, we have seen that there are teachersas-raters problems. In terms of formative assessment, the lasting influence of the summative approach in official and professional discourse continues to undermine the need to conduct long-term classroom-based and learning-oriented assessment.

Beyond the classroom-level issues, there is a more deep-seated conceptual and infrastructural question that remains unattended. A key challenge for teachers working in the assessment context described in this article is to provide feedback to learners on their English language use such that effective language development and learning takes place. For teachers to do this effectively, they need to have keen insights into the nature of language and it thus follows - as one source of this knowledge - that the official discourse should provide, centrally, guidance on how to assess cross-curricular language development for their additional language learners. It was observed above that the main reference to "language" in the DfES 2003 document was to the use of tenses (see Table 3), yet we know that teachers need to draw on a range of perspectives on language to inform their cross-curricular assessments within the English National Curriculum. Gardner and Rea-Dickins (2001), for example, noticed that the teachers in their research study drew partially on several models and views of language, including traditional grammar, notions, and functions (e.g., compare and contrast); discourse (e.g., negotiation); register; genre theory (e.g., narrative); phonics; and semantics. Even with regard to grammar, one teacher had this to say: "It's assumed that because you've got the skills to be a language support teacher that you've got a comprehensive knowledge of the grammatical structure of the language. So maybe there's a training element" (Rea-Dickins et al., 1998, p. 23).

Scott and Erduran (2004) also noted how little theoretical and empirical support is contained in another key assessment document for teachers (in England) A Language in Common (QCA, 2000). In terms of the construct of language 
underlying this document, this is not made explicit (cf. South Australian Curriculum and Standards Authority, 2002); specific additional language assessment scales are provided only for the early stages of language learning in the four skill areas and, overall, language is construed as that required for classroom purposes consistent with English as a (national curriculum) subject, with all its default assumptions of it being a mother tongue. ${ }^{10}$ The "English as an additional language" dimension is not explored as a distinctive issue from general good practice in assessment promoted in the official curriculum documents.

At this moment of a policy shift toward teacher assessment as the favoured form of levering up achievement in British education, there is a good deal of professional general public support for and professional goodwill toward this move. From the point of view of EAL teaching and learning, there remain conceptual and implementation questions that have yet to be addressed. In this discussion we have tried to show that although educational assessment policy can espouse a particular preference in terms of approaches and forms of assessment at particular moments of governance, ultimately policy is indifferent to the more technical and educational considerations. Assessment is, seen in this light, an instrument to be used to service the needs of greater social and political imperatives. At a systemic level the "difficult" trajectories of benchmarking achievement in English within the National Curriculum have shown how different approaches to assessment could be adopted as a response to perceived policy needs. At a discipline specific level the lack of an EAL-informed infrastructure in the assessment regime signals a lack of interest in what is being assessed. All this suggests that in the long run the development of equitable and educationally valid assessment will benefit from critical analysis of both policy and practice.

\section{REFERENCES}

Anonymous. (2004, March 16). Second fiddle. Guardian, p. 8.

Arizona Department of Education. (2004). The effects of bilingual education programs and structured English immersion programs on student achievement: A large-scale comparison. Retrieved September 3, 2004, from http://www.public.asu.edu/ macswan/ade/ade_document.pdf

Arkoudis, S., \& O'Loughlin, K. (2004). Tensions between validity and outcomes: teacher assessment of written work of recently arrived immigrant ESL students. Language Testing, 21, 284-304.

Assessment Reform Group. (2002). Assessment for learning: 10 principles. Retrieved October 7, 2004, from http://www.assessment-reform-group.org.uk/CIE3.pdf

Association of Teachers and Lecturers. (2005). Standards in English primary schools: are they rising? London: Author.

Barber, M. (1997). A reading revolution: How we can teach every child to read well: the preliminary report of the Literacy Task Force. London: Institute of Education.

\footnotetext{
${ }^{10}$ Official advice recommends that for summative assessment English as a Second Language pupils should be assessed on the primarily mother-tongued modeled National Curriculum English.
} 
Black, P. (1998). Testing: friend or foe? Theory and practice of assessment and testing. London: Falmer Press.

Black, P., Harrison, C., Lee, C., Marshall, B., \& Wiliam, D. (2002). Working inside the black box. London: Department of Education and Professional Studies, King's College London.

Black, P., Harrison, C., Lee, C., Marshall, B., \& Wiliam, D. (2003). Assessment for learning: Putting it into practice. Berkshire, England: Open University Press.

Black, P., \& Wiliam, D. (1998a). Assessment and classroom learning. Assessment in Education, 5, 7-73.

Black, P., \& Wiliam, D. (1998b). Inside the black box. London: King's College London.

Brindley, G. (1998). Outcomes-based assessment and reporting in language learning programs: A review of the issues. Language Testing, 15, 45-85.

Brindley, G. (2001a). Investigating rater consistency in competency-based language asessment. In G. Brindley \& C. Burrows (Eds.), Studies in immigrant English language assessment (Vol. 2, pp. 59-91). Sydney: National Centre for English Language Teaching and Research, Macquarie University.

Brindley, G. (2001b). Outcomes-based assessment in practice: some examples and emerging insights. Language Testing, 18, 393-407.

Broadfoot, P., \& Pollard, A. (2000). The changing discourse of assessment policy: the case of English primary education. In A. Filer (Ed.), Assessment: Social practice and social product (pp. 11-26). London: Routledge Falmer.

Clarke, S., \& Gipps, C. (2000). The role of teachers in teacher assessment in England 1996-1998. Evaluation and Research in Education, 14, 38-52.

Daugherty Assessment Review Group. (2004). Learning pathways through statutory assessment: Key Stages 2 and 3 (final report). Retrieved September 19, 2005, from http://www.learning.wales.gov.uk/scripts/fe/news_details.asp?NewsID $=1226$

Davison, C. (2004). The contradictory culture of teacher-based assessment: ESL assessment practices in Australia and Hong Kong secondary schools. Language Testing, 21, 305-334.

Department of Education and Employment. (1997). Excellence in schools. London: Author.

Department for Education and Employment. (1998). The National Literacy Strategy. London: Author.

Department for Education and Skills. (2004). Excellence and enjoyment. Retrieved September 9, 2005, from http://www.standards.dfes.gov.uk/primary/publications/literacy/63553/pns_excell_ enjoy037703v2.pdf

Department for Education and Skills. (2003). The assessment of pupils learning English as an Additional Language. London: Author.

Department for Education and Skills. (2005). Aiming high: Guidance on assessment of pupils learning English as an additional language. Nottingham, England: Author.

Department of Education Employment, \& Qualifications and Curriculum Authority. (1999). English - the National Curriculum for England. London: Author..

Earl, L., Watson, N., Levin, B., Leithwood, K., Fullan, M., Torrance, N., et al. (2003). Watching learning 3: Final report of the external evaluation of England's national literacy and numeracy strategies. Toronto: Ontario Institute for Studies in Education, University of Toronto.

Edelenbos, P., \& Kubanek-German, A. (2004). Teacher assessment: The concept of "diagnostic competence." Language Testing, 21, 259-283.

Gardner, S., \& Rea-Dickins, P. (2001). Conglomeration or chameleon? Teachers' representations of language in the assessment of learners with English as an additional language. Language Awareness, $10,1-7$.

Henry, J. (2001, June 29). Time has come to trust the teachers. Times Educational Supplement, p. 2. Hofkins, D. (2004, March 19). Fit for the future. Times Education Supplement, p. 2.

Honey, J. (1997). Language is power: The story of standard English and its enemies. London: Faber. Leung, C. (1999). Teachers' response to linguistic diversity. In A. Tosi \& C. Leung (Eds.), Rethinking language education: From a monolingual to a multilingual perspective (pp. 225-240). London: Centre for Information on Language Teaching and Research. 
Leung, C., \& Mohan, B. (2004). Teacher formative assessment and talk in classroom contexts: Assessment as discourse and assessment of discourse. Language Testing, 21, 335-359.

Leung, C., \& Teasdale, A. (1997). Raters' understanding of rating scales as abstracted concept and as instruments for decision-making. Melbourne Papers in Language Testing, 6, 45-70.

Loewen, S. (2004). Uptake in incidental focus on form in meaning-focused ESL lessons. Language Learning, 54, 153-188.

Lumley, T. (2002). Assessment criteria in a large-scale writing test: what do they really mean to the raters? Language Testing, 19, 246-276.

McNamara, T. (1996), Measuring second language performance. Harlow, England: Addison Wesley Longman.

Mitchell, R. (2001). Prescribed language standards and foreign language classroom practice: Relationship and consequences. In C. Elder, A. Brown, E. Grove, K. Hill, N. Iwashita, T. Lumley, T. McNmara, \& K. O'Loughlin (Eds.), Experimenting with uncertainty: Essays in honour of Alan Davies (pp. 163-176). Cambridge, England: Cambridge University Press.

National Languages and Literacy Institute of Australia. (1994). ESL development: Language and literacy in schools (Vol. 1). Canberra, Australia: Department of Employment, Education and Training.

National Statistics-Department for Education and Skills. (2005). National curriculum Assessments of 11 year olds in England, 2005 (provisional). London: Department for Education and Skills.

O'Sullivan, B., Weir, C., \& Saville, N. (2002). Using observation checklists to validate speaking test tasks. Language Testing, 19, 33-56.

Panova, I., \& Lyster, R. (2002). Patterns of corrective feedback and uptake in an adult ESL classroom. TESOL Quarterly, 36, 573-595.

Qualifications and Curriculum Authority. (2000). A language in common: Assessing English as an Additional Language. London: Author.

Qualifications and Curriculum Authority. (2004a). New assessment arrangements for key stage 1. Retrieved September 23, 2004, from http://www.qca.org.uk/ages3-14/tests_tasks/2632.html

Qualifications and Curriculum Authority. (2004b). Years 1 and 2 and reception: Assessment and reporting arrangements. London: Author.

Rea-Dickins, P. (2001). Mirror, mirror on the wall: Identifying processes of classroom assessment. Language Testing, 18, 429-462.

Rea-Dickins, P. (2002). Classroom assessment of English as an Additional Language: Key Stage 1 contexts. End of award report (ESRC Major Research Grant R000238196, 1999-2002). Available at http://www.esrcsocietytoday.ac.uk/ESRCInfoCentre/ViewAwardPage.aspx?data=\%2fFrXHT 1993oBn\%2f\%2fgKlxUDEIxcnfn8e239BDDlp\%2bm1I\%2bm6emcHyDKWZ7TMEGM2bJU2qz J50GDTUby6Uo5DVZa\%2bBcAyOdnGuigPWmgeyNVMuFZlkf7YoBLXdkPuO1M4AOHCO4t NYcT\%2b6Kt81HssQ0y2wCwEq3iwJEOyWU5omc205GxRMreCQFwK7SnTnLidVw4bi3xCS VRiShvWQbEJccIriFAZZ6VHjOQHU7RpQ\%2fizG4EkeMx\%2bJCHmioV0k86nxbNaeXBnTLa ZLbN46sYYv8G31h8oCFd2meycomS90BhRHM\%3d\&xu=\&isAwardHolder=\&isProfiled=\& Award HolderID $=\&$ Sector $=$.

Rea-Dickins, P. (2006). Currents and eddies in the discourse of assessment: A learning-focused interpretation. International Journal of Applied Linguistics, 16, 164-189.

Rea-Dickins, P. (2007). Learning or measuring? Exploring teacher decision-making in planning for classroom-based language assessment. In S. Fotos \& H. Nassaji (Eds.), Form-focused instruction and teacher education: Studies in honour of Rod Ellis (pp. 195-211). Oxford, England: Oxford University Press.

Rea-Dickins, P., \& Gardner, S. (with Clayton, E.) (1998). Investigating the language assessment of learners with EAL (Report for Minority Group Services, Coventry City Council Education Service). Warwick, England: University of Warwick.

Rea-Dickins, P., \& Gardner, S. (2000). Snares or silver bullets: Disentangling the construct of formative assessment. Language Testing, 17, 215-243. 
Rezzonico, A. (2004). Horne releases study showing Arizona students in Structured English Immersion outperformed students in bilingual (News Release 2004 - 08-05). Arizona: Arizona Department of Education. Scott, C. (2005). Washback in the UK primary context with EAL learners: Exploratory case studies. Unpublished doctoral thesis, Graduate School of Education, University of Bristol, Bristol, England.

Scott, C., \& Erduran, S. (2004). Learning from international frameworks for assessment: EAL descriptors in Australia and the USA. Language Testing, 21, 409-424.

South Australian Curriculum and Standards Authority. (2002). South Australian curriculum standards and accountability framework: English as a second language. Adelaide, Australia: Department of Training and Employment.

Spencer, J. (Ed.). (2004, January). Teachers, 30. London: Department for Education and Skills. Available from www.teachernet.gov.uk

Spencer, J. (Ed.). (2003, November). Teachers, 29. London: Department for Education and Skills. Available from www.teachernet.gov.uk

Teachers of English to Speakers of Other Languages Inc. (1997). ESL standards for pre-K-12. Alexandria, VA: Author.

Teachers of English to Speakers of Other Languages Inc. (2004). TESOL response to the Arizona Department of Education study on student achievement in structured English immersion programs. Retrieved September 16, 2005, from www.tesol.org/s_tesol/bin.asp?TrackID=\&SID=1\&DID= $2627 \& \mathrm{CID}=1 \& \mathrm{VID}=2 \& \mathrm{DOC}=$ File.PDF

Teasdale, A., \& Leung, C. (2000). Teacher assessment and psychometric theory: a case of paradigm crossing. Language Testing, 17, 163-184.

Timms, P. (2004). Are standards rising in English primary schools? British Educational Research Journal, 30, 477-494.

Timms, P. B., \& Fitz-Gibbon, C. (2001). Standards, achievement and educational performance: a cause for celebration? In R. Phillips \& J. Furlong (Eds.), Education, reform and the state: Twentyfive years of politics, policy and practice (pp. 156-173). London: Routledge Falmer.

Torrance, H. \& Pryor, J. (1998). Investigating formative assessment: Teaching, learning and assessment in the classroom. Buckingham, England: Open University Press.

Tunstall, P., \& Gipps, C. (1996). Teacher feedback to young children in formative assessment: a typology. British Educational Research Journal, 22, 389-416.

Ward, H. (2004, March 19). Targets that miss the point. Times Educational Supplement, p. 18.

Wiliam, D. (2001a). An overview of the relationship between assessment and the curriculum. In D. Scott (Ed.), Curriculum and assessment (pp.165-181). Westport, CT: Ablex.

Wiliam, D. (2001b). Reliability, validity, and all that jazz. Education, 3, 17-21.

Wilce, H. (2003, November). Measuring up. Teachers Magazine (Primary School). Available from http://www.teachersnet.gov.uk

\section{APPENDIX A Glossary}

Advanced Level examinations: Matriculation examinations for school students at the age of 18 (approx) in England and Wales; the results of these examinations are used by British universities for admissions/selection purposes.

Local Education Authority (LEA): Schools in England and Wales are organized and administered by local (county or city borough level) government. LEAs also provide some in-service teacher professional training and development. 
National Curriculum (England and Wales): The National Curriculum, introduced through the Education Reform Act (1989), provides subject curriculum (e.g., English and Mathematics) specifications for school education in England and Wales. These curriculum specifications are, technically speaking, statutory. Scotland and Northern Ireland are under separate educational administration.

National Literacy Strategy (NLS): The NLS (DfES, 1998) was introduced by the British Government as a special initiative, within the National Curriculum, to boost the policy of increasing the literacy skills of school pupils in England and Wales. There was also a National Numeracy Strategy. These two Strategies have now been merged into a single National Strategy.

\section{APPENDIX B}

National Curriculum English Level 4 (Department for Education and Skills, 1999)

\section{Speaking and Listening}

Pupils talk and listen with confidence in an increasing range of contexts. Their talk is adapted to the purpose: developing ideas thoughtfully, describing events and conveying their opinions clearly. In discussion, they listen carefully, making contributions and asking questions that are responsive to others' ideas and views. They use appropriately some of the features of standard English vocabulary and grammar (p. 55).

\section{Reading}

In responding to a range of texts, pupils show understanding of significant ideas, themes, events and characters, beginning to use inference and deduction. They refer to the text when explaining their views. They locate and use ideas and information (p. 57).

\section{Writing}

Pupils' writing in a range of forms is lively and thoughtful. Ideas are often sustained and developed in interesting ways and organised appropriately for the purpose of the reader. Vocabulary choices are often adventurous and words are used for effect. Pupils are beginning to use grammatically complex sentences, extending meaning. Spelling, including that of polysyllabic words that conform to regular patterns, is generally accurate. Full stops, capital letters and question marks are used correctly, and pupils are beginning to use punctuation within the sentence. Handwriting style is fluent, joined and legible (p. 59). 


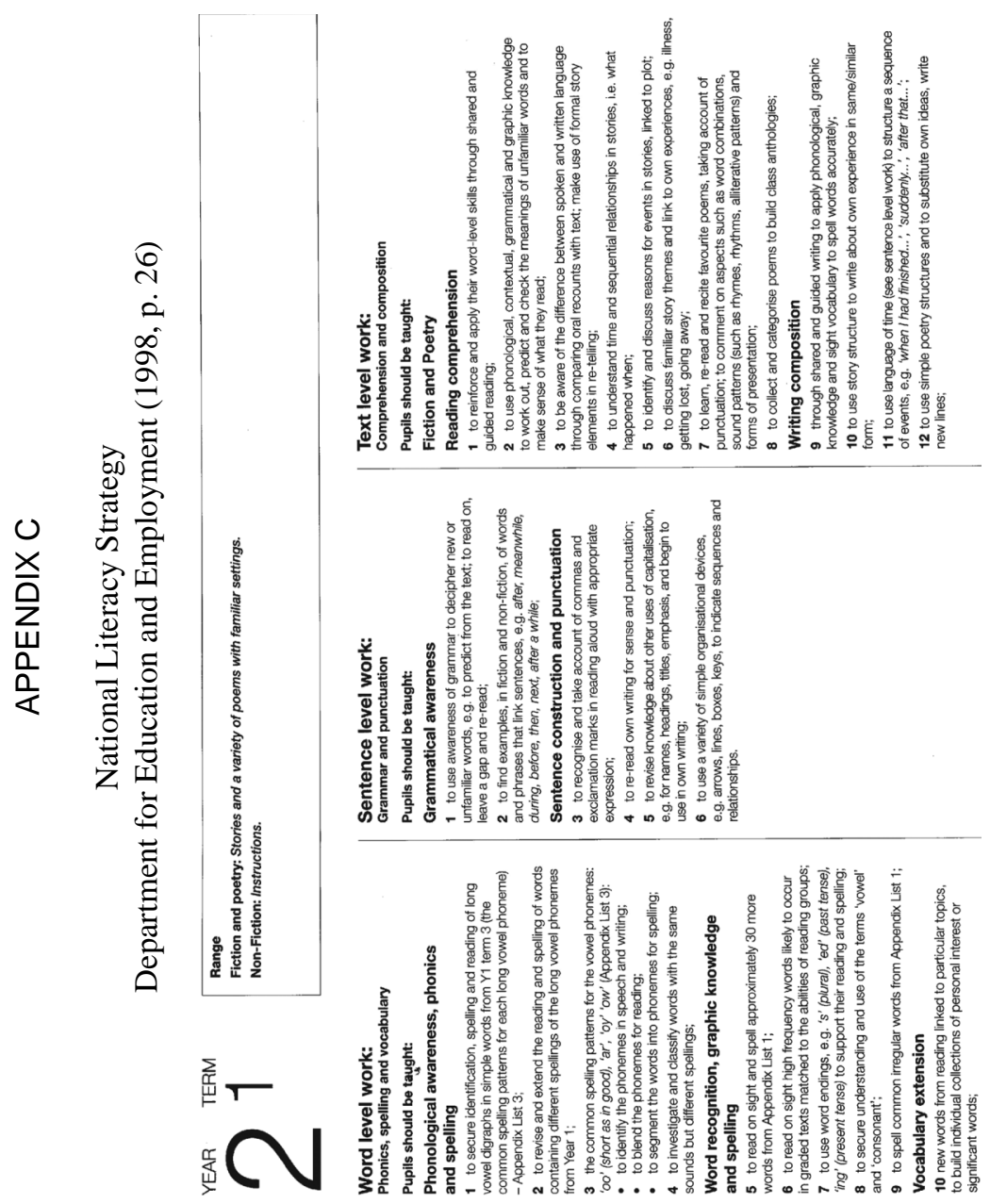




\section{APPENDIX D}

The Literacy Hour

Department for Education and Employment (1998, p. 9)

\section{Structure of the Literacy Hour}

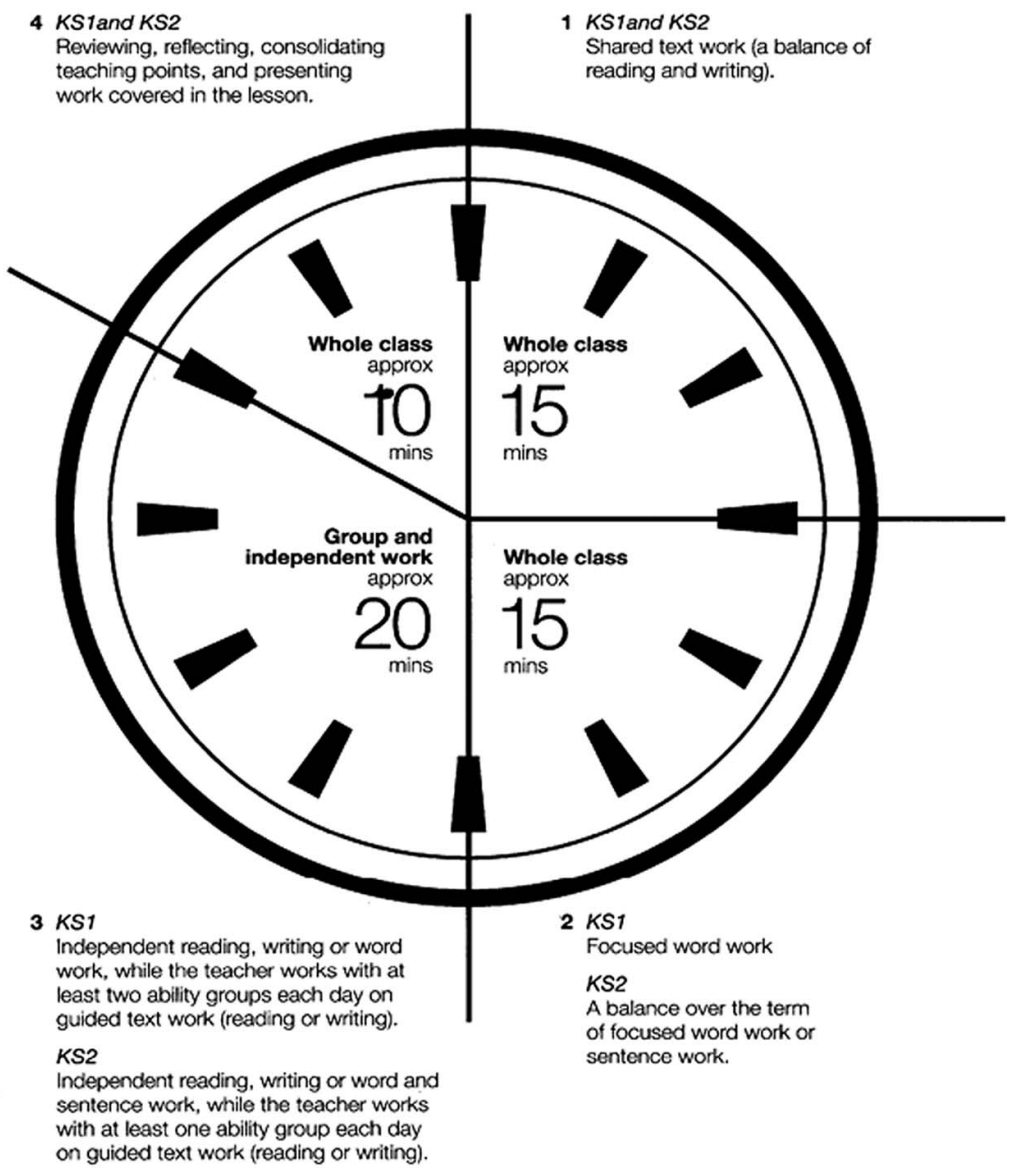




\section{APPENDIX E}

\section{Section 3: Using data to inform teaching and learning}

'... the data provide a baseline to monitor and review individuals' progress - especially to identify signs of underachievement or unusual potential . ..' (Ofsted 2003)

'Setting targets will not, on its own, raise standards of achievement. This will depend on the timely and skilful intervention by teachers and other professionals, and the support of parents.' (Ofsted 2003)

The following two case studies show how two schools are using data to plan interventions and to monitor and track the progress of targeted pupils learning EAL.

\section{Case Study School A}

(An inner city school with large numbers of pupils learning EAL and regular new arrivals)

All teachers are provided with data on all pupils for the classes they teach. In addition to the essential support provided for new arrivals, the school has prioritised the majority of its EAL resources on Year 7 and in providing support in English lessons in particular this year. This approach will be monitored and reviewed. All incoming pupils are set minimum targets for the end of each of the three years at Key Stage 3, setting a trajectory for progress towards end of key stage targets in the core subjects. These are reviewed each term. To this end, in this school, National Curriculum levels are divided into 'insecure' 'competent' and 'confident', based on the raw scores in English on the Key Stage 2 tests.

Using a range of data, pupils in each Year 7 tutor group are identified by the EMA team. These pupils are clearly highlighted on tutor group lists given to all teachers. EMA teachers also disseminate information regarding the pupils' home language competence to all mainstream staff. This ensures that the progress of all pupils for whom English is an additional language is monitored, including more advanced learners who may still require support, particularly with writing.

Support is monitored through an intervention sheet that describes the type of support given, Through a writing analysis carried out each half term, three individual targets are agreed with the pupil. EMA teachers set up an individual file for each targeted pupil containing the analysed writing samples and reviewed targets. These are also available to other Year 7 tutors and teachers on the IT network.

In lessons where support is allocated, assessment is carried out by both the mainstream and EMA teacher throughout the year. Both teachers mark work 
(split 50/50) and write profiles using National Curriculum levels for reading, writing, speaking and listening for all pupils in the class. Partnership teaching has enabled English and EMA teachers to see the improvements that can be made, particularly through a word and sentence level focus. Aspects of the Key Stage 3 Strategy and an explicit focus on the teaching of language skills are now accepted as good practice and are being applied more widely across subjects and year groups.

In addition to the day-to-day targeted support, the EMA team has sampled and analysed the writing of a sample of insecure National Curriculum level 4 pupils across the curriculum at word, sentence and text level to identify common difficulties. The next stage of their work is to turn these into literacy targets and support colleagues in addressing common literacy needs in lessons where there is currently no available support.

\section{Case Study School B}

(An inner city school with a high percentage of pupils learning EAL although most pupils are UK born and have full primary experience)

The EMA team is aware that many pupils learning EAL need continuing support with their English in order to maximise their attainment even though many may have reached level 4 on entry. The data from CATS used by the school shows clear discrepancies between low verbal scores and higher quantitative and non-verbal scores for many pupils.

EMA teachers have attempted to identify able but underachieving pupils for targeted support, noting particular problems with reading comprehension as well as difficulties with writing in English. Through a detailed analysis of the written scripts of these pupils, the team has identified 14 areas of difficulty and common error and have linked these to text, sentence and word level objectives of the Key Stage 3 Strategy English Framework. 